\title{
Global Economic Consequences of the Latest Federal Reserve Policy Tool
}

\author{
David M. Gordon \\ University of Saint Francis (IL) \\ 500 Wilcox St., Joliet, IL \\ USA
}

\begin{abstract}
The Federal Reserve System(Fed) plays a vital role in our economy as our central bank. The main purpose of this paper is to show how the Fed's newest policy tool can impact the exchange rate (and thus trade patterns) within a country. This paper will review the three traditional functions of the Federal Reserve System with regards to monetary policy. It is imperative that anyone with economic interests understand the importance of this role. Knowledge of how the Fed or any central bank conducts monetary policy has become even more important to grasp given the recent worldwide falls in stock valuations as well as the still unfolding events in Great Britain (Brexit). A brief history of the Fed is also provided. Many economic participants are not aware of when the central bank first arrived in our economy. The roles and functions of the Fed are explored in the paper as well. This paper also offers an explanation of the traditional tools the Fed uses to conduct monetary policy. Open market operations are explained. The important role of the discount rate is discussed. The required reserve ratios are also explored. The newest tool of the Fed is their ability to pay interest on deposits that member banks keep at the Fed. This new tool is explained and its' ramifications on exchange rates are explored.
\end{abstract}

Keywords: Monetary policy, exchange rates, Federal Reserve tools

\section{Introduction}

The main purposes of this paper are to review the traditional functions of the Federal Reserve System with regards to monetary policy, explain the new tool the Fed has adopted and to provide extensive information on how this new tool can effect exchange rates. Familiarity of how the Fed or any central bank conducts monetary policy has become even more significant to grasp given the recent worldwide depressed stock markets as well as the current events unfolding in Europe with Great Britain leaving the European Monetary Union. A brief history of the Fed itself is delivered. The paper then expands on how the Fed has traditionally conducted monetary policy. In recent times the Fed has started to pay interest on demand deposits that are placed at the Fed. This is a very recent occurrence. This payment of interest operates as a fourth tool of conducting monetary policy. It is one the Fed seemingly relies on more and more in recent times. The relative value of this tool in impacting interest rates and exchange rates is discussed in this paper as well.

\section{Brief History of Global Economics}

Economies were not always as intricately linked together as they now are. Societies were initially arranged as tradition based economies which produced all the necessary goods on their own. As populations increased individuals saw the advantages in trading with others. This is where the global economy really began. There were no theories on economics existing in these times, but people simply acted in their own best interest and started bartering with others.

Up until the $18^{\text {th }}$ century nations traded based on the irrational theory of mercantilism. This theory suggested that whoever had the most gold and silver was the richest nation. This explains the ventures into Central and South America by the Spanish and other colonial type of ventures by various wealthy European countries at the time. In 1776, Adam Smith published what is considered the first textbook in economics, The Wealth of Nations. This book laid down the theory of absolute advantage which stated why trade patterns would develop in the first place. The book also discredited the mercantilist viewpoint. Another classical economist, David Ricardo, introduced an alternative theory of trade called comparative advantage. This stated that whoever had the lowest relative opportunity cost would specialize in the production of that good or service. This is the theory that still dominates today. Trade would then take place across the various nations. The terms of trade (prices) would be arrived at based on supply and demand conditions that prevailed for particular goods/services. The amount of trade that took place among nations depended in part on the modes of transportation that were developed over time. Better transportation meant the price of exported goods would be cheaper and thus the demand higher. 
Trade volumes increased over time up until around 1930. In 1930 the Smoot-Hawley Tariff Act was passed. This increased tariffs on several imported goods. (A tariff is a tax on imports which you will be studying shortly.) Other nations then began to pass their own trade laws increasing tariffs and non-tariff barriers to trade. This reciprocating behavior led to a substantial drop in trade. The Smoot-Hawley Tariff is thought to have at a minimum contributed to the world depression during the 1930's. Some economists claim that it actually instigated the Great Depression.

After World War II several developed nations came together under the auspices of GATT (general agreement on tariffs and trade). The initial GATT round of talks was held in 1947. The first few rounds of GATT meetings resulted in a big reduction in tariffs and a few reductions in non-tariff barriers to trade. In 1962 GATT rounds began to take on names of people (Kennedy Round) or places where the meetings originated (Tokyo Round). GATT eventually became the World Trade Organization (WTO). The current WTO round is the Doha Round which to date has been the first unsuccessful round of trade talks.

Our economies are also more and more linked together through "trade" in finances. Our financial markets have also become globalized. It is quite common for individuals or institutions in one country to invest in the financial assets being offered in other countries. As we see today the financial markets are linked together. One of these main linkages are the variety of exchange rates that exist in our global economy. Central bank policies that effect interest rates and inflation rates are main determinants of currency prices.

\section{Brief History of The Fed}

The United States did not always have a central bank. When the country was first formed private banks were the only banks that existed. The private banks existed as unit type banks in the various states. The legitimacy of the currency that each bank printed was always in question. Many banks printed too many dollars relative to their actual deposits. This led to these currencies being worth less than the currencies issued by a bank that was more conservative in printing money. It was difficult for merchants to know which currency was inflated and which was not given the many hundreds of banks in existence. Counterfeit currency was another problem that existed at the time. Although the penalties for counterfeiting were quite harsh it still existed. The First Bank of the United States was formed in 1791. It was given a twenty-year national charter. The bank functioned in some ways as our central bank functions today. It became the official bank for the US government much as the Fed is today. It did lack the important advanced money creation function though. The uniform currency that it produced led to several economic efficiencies in our economy. The bank directly competed with state banks and was continuously under political pressure to close. When the charter expired the bank ceased to exist. This left a few years where the country did not have a national bank. The Second Bank of the United States was chartered in 1817. This bank functioned much like the First Bank of the United States, but was much larger. The capitalization for the second bank was $\$ 35$ million while the first bank had a capitalization of only $\$ 10$ million. This new national bank had 25 branches scattered across the country much like our modern day central bank. The Second Bank of the United States closed after its initial charter ran out. President Andrew Jackson was not a big fan of banks and refused to renew the charter.

The issue of a uniform currency or a central bank did not come up until very early in the $20^{\text {th }}$ century. The idea was still very controversial at the time. The Federal Reserve Act was finally passed in late 1913 after much discussion and debate. The structure and responsibilities of the Fed were significantly different than the structure and responsibilities of the Fed today. The discount window lending function was more prominent then for example. Since the inception of the Fed it was apparent that this central bank was going to have a major impact on national economic and financial policy. Ensuing legislation such as the banking Act of 1935, the Employment Act of 1946, the Full Employment and Balanced Growth Act (Humphrey-Hawkins Act) of 1978, and the Depository Institutions Deregulation and Monetary Control Act (DIDMCA) of 1980 made the responsibilities of the Fed broader and more complex. Monetary policy has historically been implemented via the federal funds rate. This rate has been controlled by three main tools: open market operations, discount window lending and control of the legally required reserve ratios. These tools are utilized by the Federal Open Market Committee (FOMC) of the Fed. The FOMC consists of the seven members of the Board of Governors (the Board consist of Presidential appointees who are confirmed by the US Senate), the president of the New York Federal Reserve Bank and presidents of four other district Federal Reserve banks (there are twelve altogether) who serve on a rather complex rotation schedule.

With regards to monetary policy the FOMC can either target monetary aggregates, such as M2, or interest rates. The Fed has done both over time. Prior to the 1980's the focus was mainly on monetary aggregates. Beginning in the early 80's the Fed started targeting the federal funds rate instead of monetary aggregates. This was in part due to the significant amount of deregulation that occurred. The Fed still targets interest rates over monetary aggregates. 


\subsection{Tool Number One: The Discount Rate}

The role of the discount rate has diminished over time. When the Fed first began operations the discount rate was a main tool used in conducting monetary policy. Today it only has a minor status. The discount rate is now set slightly above prevailing short term market rates such as the rate on federal funds. During various crises discount window lending does increase. In normal times though discount window lending only complements open market operations and serves as a secondary source of liquidity for depository institutions.

The Fed extends credit to financial institutions under three various credit programs. These are entitled primary credit, secondary credit and seasonal credit. Primary credit is available only on a very short term basis generally overnight. The institutions receiving this type of credit are normally very sound financially. The rate on this credit is typically priced about $1 \%$ above the current federal funds rate, but the deviations can be substantial over time. The rate on primary credit is normally what is also referred to as the discount rate. Secondary credit is also extended on a very short term basis once again typically overnight. This is given to institutions who do not qualify for primary credit. The rate is thus higher on this type of credit. Normally a 50 basis point spread exists between primary and secondary credit. Seasonal credit is provided to institutions that can clearly demonstrate a pattern of recurring swings in funding needs throughout the year. Institutions operating in agricultural areas would be one example of an institution who could qualify for seasonal credit. The rate is usually set at a few basis points above the federal funds rate. All loans granted via the discount window must be secured by collateral. What constitutes proper collateral has changed over time and becomes much more liberal in times of financial crises.

An increase in the discount rate (meaning all types of credit explained above) would cause financial institutions to borrow less from the discount window. This would then cause the money supply to contract. This is referred to as the cost effect. A decrease in the discount rate causes the opposite effects and thus the money supply would increase. Any policy that causes the money supply to increase is considered an expansionary monetary policy. Any policy change that causes the money supply to contract is referred to as a contractionary monetary policy. There is also a substitution effect and an announcement effect that is caused by a change in the discount rate. The substitution effect causes changes in the discount rate to impact other short term market rates. The announcement effect acts as a signaling to the market of future Fed plans.

An increase in the discount rate would cause the value of a currency to appreciate in a country due to the positive impact on interest rates in general. The contractionary impact of the higher discount rate would be augmented by the higher currency price which would make exports more expensive and imports cheaper.

\subsection{Tool Number Two: Required Reserve Ratios}

Depository institutions are required to maintain a certain percentage of their various liabilities in the form of required reserves. These reserves can be kept in the form of vault cash or in demand deposits at the Fed. Smaller institutions are subjected to lower rates than larger institutions. Demand deposits are typically subjected to higher reserve requirements than time deposits or Eurocurrency liabilities.

Prior to around 1980 the Fed actively used reserve requirements to conduct monetary policy. By the time 1980 came around the financial environment had changed dramatically due to the deregulation that occurred over the past couple of decades. The Monetary Control Act was instituted in 1980 and placed all depository institutions under the reserve requirements regardless of if the institution is a member of the Fed. The reserve requirements were not changed again until 1990. There were reductions in many of the reserve ratios at that time. This was due to a sense that financial institutions had adopted more conservative approaches to lending funds. Since that time there has been no substantial changes in reserve ratios.

Changes in the legal reserve requirements effect the financial system in three different ways. The legally required reserve ratios are parts of the money multiplier. When there is an increase in the reserve requirements the money multiplier shrinks. A decrease in reserve requirements causes the money multiplier to expand. When the money multiplier increase the money supply also increases thus a decrease in required reserve ratios would be an expansionary monetary policy. If the money multiplier drops the quantity of money in the economy also decreases implying that an increase in reserve ratios is a contractionary monetary policy.

Changes in the reserve ratios can also affect the mix between excess and required reserves. If legally required reserve ratios are reduced then a portion of the required reserves within the banking system now become excess reserves instead. These of course can then be loaned out which means the money supply would expand. There would be a contractionary impact on the money supply if the mix changed in the opposite direction. 
Interest rates are also influenced by reserve requirements. Higher reserve requirements will lead to higher short term interest rates as depository institutions act to cover any reserve deficiencies. In other words, the demand for short term loanable funds will increase causing a rise in rates. The opposite would occur if reserve ratios were to decline.

An increase in the legally required reserve ratios would cause the value of a currency to appreciate in a country due to the positive impact on interest rates in general. The contractionary impact of the higher reserve ratios would be augmented by the higher currency price which would make exports more expensive and imports cheaper.

\subsection{Tool Number Three: Open Market Operations}

Open market operations are the most used tool of the Fed. The FOMC meets about every six weeks unless a calamity of some sort requires the group to meet more frequently. The main decision at these meetings regards the appropriate open market operations that should take place over the ensuing six weeks. The Fed has focused on two primary targets: monetary aggregates, such as M1 and M2, and the federal funds rate. (The federal funds rate is a short term interest rate that has a direct impact on other short term market rates.)Up until the late 1970's the Fed targeted the federal funds rate. They would choose a rate that would be consistent with their long range growth target for M1. This changed in 1979 when the Fed started to directly target monetary aggregates and left the federal funds rate to change on its own. By the mid 1980's this focus changed back to where it still is now which is on the federal funds rate.

The Fed traditionally has kept US Treasury securities as one of their main assets. These vary in both denomination and time to maturity. Normally the vast bulk of securities have been in shorter term instruments mainly Treasury bills with maturities less than a year. This is due to the short term interest rate focus that the Fed usually has adopted. In recent times the balance sheet of the Fed has changed dramatically and now includes substantial holdings of longer term debt items. The "quantitative easing" that has occurred the past few years has targeted long term rates, but the Fed still targets short term rates as well.

When the Fed engages in an open market purchase this increases the money supply. The Fed is essentially replacing relatively illiquid assets with liquid assets (money) that can be immediately spent on goods and services. This would be considered an expansionary monetary policy. An open market sale is the opposite. The Fed actively sells relatively illiquid assets and reduces the amount of near money items in the economy. This is a type of contractionary monetary policy.

An open market sale would cause the value of a currency to appreciate in a country due to the positive impact on interest rates in general. The contractionary impact of the open market sale would be augmented by the higher currency price which would make exports more expensive and imports cheaper.An open market purchase would cause the value of a currency to depreciate in a country due to the negative impact on interest rates in general. The expansionary impact of the open market purchase would be enhanced by the lower currency price which would make exports cheaper and exports more expensive.

\subsection{Tool Number Four: Interest Payments On Demand Deposits At The Fed}

The first three tools of the Fed are normally the ones studied in undergraduate economics/finance classes. Textbooks still present the toolbox of the Fed as just containing these three tools, but recently a new tool has developed and could possibly be the strongest tool the Fed has in managing control of the money supply. Until a few years ago the Fed has not paid interest on any deposits kept with them in the form of reserves. A financial institution could hold reserves in either vault cash or in a demand deposit at the Fed that earned zero interest. The zero interest rate acts like a tax on deposits at the Fed. This made the two forms of reserve holdings equal as far as return goes. Financial institutions found it more efficient to hold most of their reserves at the Fed instead of in vault cash.

The Financial Services Regulatory Relief Act of 2006 authorized the Fed to pay interest on balances at Federal Reserve Banks. (These balances include required reserve balances and excess reserve balances.) The Fed initiated interest payments in 2008. The payment of interest on demand deposits can be a very strong determinant of the money supply. The current rate offered on such deposits is 25 basis points. This far exceeds the interest rate currently offered on most savings accounts in the United States. Given the risky financial and economic environment that presently prevails the $0.25 \%$ risk free rate of return appears very attractive to banks given that U.S. T-bills are paying substantially less than $0.25 \%$ at the moment. The current Fed rate acts as a brake on the creation of new loans and thus a brake on the money supply growth. Excess reserves are encouraged under this type of system. The present concern with inflation seems to be outweighing the concern with unemployment and economic growth thus the generous rate of return on demand deposits at the Fed. This new tool of the Fed seems to trump the other tools at the moment. Open market operations seem more concerned with keeping long term rates low. The payment of interest on demand deposits at the Fed is more concerned with keeping inflation in check. 
If and when the Fed decides to drop this rate below the prevailing market short term rates the money supply has a great chance of increasing by a substantial amount. On the other hand the Fed can always increase this rate from the current 25 basis points. This would have the opposite effect on the money supply.

\section{The Use Of Tool Number Four As A Monetary Sterilization Tool}

All four Fed policy tools can be utilized to accomplish the same goal whether it be an easier monetary policy (lower interest rates) or a more austere monetary policy (higher interest rates). For example, if the Fed wanted to lower interest rates they could pursue open market purchases, lower discount rates, lower legally required reserve ratios and the payment of lower interest rates on commercial bank deposits at the Fed. Everything else equal the lower interest rates would of course cause the dollar to depreciate vis-a-vis other currencies. Thus interest rate goals would partially dictate exchange rates. The beauty of the fourth and newest policy tool, paying interest on commercial bank deposits, is that it most easily allows the Fed to somewhat sterilize the effects of traditional monetary policy tools on exchange rates. For example, the Fed could engage in open market operations that would expand the monetary base, thus reducing interest rates and causing the currency value to fall, but at the same time increase the interest rates paid on commercial bank deposits which would cause banks to hold more excess reserves. This would have a mitigating effect on the drop in the currency value without having any tangible effect on the underlying monetary base. As long as the Fed paid higher rates on their deposits than banks could get on loans they created the exchange rate would appreciate. If the Fed paid a lower rate than what banks could get in the loan market then the currency would depreciate.

\section{Conclusion And Summary}

The Fed still uses all three traditional tools: reserve ratios, discount rate changes and open market operations. The effects of these changes on the exchange rate are well documented although the precise weighting of the effects on currency prices are difficult to pinpoint. The newest tool in the Fed toolbox is the payment of interest on demand deposits kept by commercial banks at the Fed. This is still in a learning stage as far as figuring out the exact implications for exchange rates and other variables. It will be difficult to measure how banks and foreign exchange markets will react to a change in the rate since it has not been changed from the 25 basis points it is currently at. The sensitivity of new money creation to changes in the interest rate paid by the Fed will be difficult to predict as will movements in currency prices. We know the directional changes that will occur, but the magnitude of changes is hard to predict. It might be the case that financial institutions will be extraordinarily cautious and not react to a drop in the rate by creating new loans, thus having only a minor impact on exchange rates. If their risk aversion lessens then the effects on exchange rates could be more substantial.

\section{References}

Burger, Albert E., The Money Supply Process, Wadsworth Publishing, Belmont, CA, 1971.

Campbell, Colin D. and Rosemary G. Campbell, An Introduction to Money and Banking, $5^{\text {th }}$ Ed., Dryden Press, New York, NY, 1984.

Cecchetti, Stephen G., Money, Banking and Financial Markets, $2^{\text {nd }}$ Ed., McGraw-Hill, New York, NY, 2008.

Friedman, Milton, Money Mischief, Harcourt Brace, Orlando, FL 1994.

Gordon, David M., (2012). The Federal Reserve Bank's New Monetary

Policy Tool.Journal of Business and Economic Research.10 (September): 533 - 538.

Gordon, David M., (2013). The Mysterious Fourth Tool of the Fed.Journal of Business and Economics. 4 (May):375 380.

Gordon, Robert J., Macroeconomics, $12^{\text {th }}$ Ed., Addison-Wesley, Boston, MA, 2012.

Hubbard, R. Glenn, Money, the Financial System and the Economy, ${ }^{\text {th }}$ Ed., Pearson, Boston, MA, 2008.

Melton, William C., Inside the Fed: Making Monetary Policy, Dow-Jones Irwin, New York, NY 1985.

Miller, Roger LeRoy and David D. VanHoose, Money, Banking and Financial Markets, $3^{\text {rd }}$ Ed., ThomsonSouthwestern, Mason, OH, 2007.

Ritter, Lawrence S., Silber, William L. and Gregory F. Udell, Money, Banking and Financial Markets, AddisonWesley, Boston, MA, 2009.

Rose, Peter S. and Sylvia C. Hudgins, Bank Management and Financial Services, $8^{\text {th }}$ Ed., McGraw-Hill, New York, NY, 2010.

Rose, Peter S. and Milton H. Marquis, Money and Capital Markets, 10th Ed., McGraw-Hill, New York, NY, 2008.

Selgin, George, Floored, Cato Institute, Washington, D.C., 2018. 